\title{
A LIBERDADE DECORRENTE DA SELEÇÃO DO "MELHOR" EMBRIÃO MEDIANTE O DIAGNÓSTICO GENÉTICO PRÉ -IMPLANTACIONAL
}

\author{
Janaína Vandresen ${ }^{1}$ \\ Rita de Cassia Resquetti Tarifa Espolador ${ }^{2}$ \\ Fernando Ono Martins ${ }^{3}$
}

\begin{abstract}
Resumo: Com o avanço da engenharia genética, tornou-se possível selecionar artificialmente um embrião com a finalidade de gerar um filho sem as alterações genéticas causadoras de doenças, mediante o diagnóstico genético pré-implantacional (DGPI). Diante desse cenário tecnológico, este artigo tem por objetivo identificar qual o tipo de liberdade se amolda ao fato de o indivíduo selecionar o "melhor" embrião pela técnica do DGPI. Para tanto, serão apresentados alguns conceitos e classificações de liberdade, com enfoque na distinção entre positiva e negativa defendida por Isaiah Berlin, a fim de se alcançar o significado de liberdade adequado ao contexto desta discussão biojurídica.
\end{abstract}

Palavras-chave: Liberdade positiva. Liberdade negativa. Biodireito. "Melhor" embrião. Diagnóstico genético pré-implantacional.

\section{FREEDOM ARISING FROM THE SELECTION OF THE "BEST" EMBRYO THROUGH THE PREIMPLANTATION GENETIC DIAGNOSIS}

\begin{abstract}
With the advance of genetic engineering, it has become possible to artificially select an embryo in order to produce a child without the disease-causing genetic changes through the preimplantation genetic diagnosis. Given this technological scenario, this article aims to identify which type of freedom is shaped by the fact that the individual selects the "best" embryo using the PGD technique. For that, some concepts and classifications of freedom will be presented, focusing on the distinction between positive and negative defended by Isaiah Berlin, in order to reach the meaning of freedom appropriate to the context of this biojuridical discussion.
\end{abstract}

Keywords: Positive freedom. Negative freedom. Biolaw. "Best" embryo. Preimplantation genetic diagnosis.

\section{INTRODUÇÃO}

\footnotetext{
${ }^{1}$ Mestranda em Direito Negocial pela Universidade Estadual de Londrina. Pós-graduada em Direito Privado pela Uniderp/Anhanguera e em Direito Aplicado pela Escola da Magistratura do Estado do Paraná. Servidora Pública Federal. E-mail: janaina_vandresen@hotmail.com.

2 Doutora em Direito Civil pela Universidade Federal do Paraná. Mestre em Direito Negocial pela Universidade Estadual de Londrina, Docente do Programa de Mestrado em Direito Negocial da Universidade Estadual de Londrina. Advogada. E-mail: rita.tarifa@gmail.com.

${ }^{3}$ Mestrando em Direito Negocial pela Universidade Estadual de Londrina. Pós-graduado em Direito Civil pela Universidade Anhanguera-Uniderp. Procurador Federal/AGU. E-mail: fernandoonomartins@outlook.com
} 
A possibilidade de selecionar artificialmente um embrião com a finalidade de gerar um filho sem as alterações genéticas causadoras de doenças adveio do avanço da engenharia genética e das técnicas de reprodução assistida, passando a ser permitido no Brasil por meio da Resolução do Conselho Federal de Medicina n. ${ }^{\circ}$ 2168/2017.

Em outros países, é até mesmo legal a seleção de atributos mais específicos, tais como o sexo do embrião, como indiscriminadamente ocorre nos Estados Unidos da América, local em que muitos casais estrangeiros com poder aquisitivo alto se dirigem a fim de realizar os procedimentos médicos para escolha do sexo de seus bebês. Inclusive, essa prática de seleção do sexo de embrião também é permitida na Austrália, mas sob a condição de que seja para evitar uma doença hereditária.

Além disso, hoje é prática comum a reprodução independente por meio de escolha ou até mesmo compra em sites internacionais de gametas em bancos de doadores, tais como, Fairfax Cryobank, Seattle Sperm Bank e Califórnia Cryobank. Por meio deles, é possível selecionar as características fenotípicas destes, inclusive analisar foto de quando era criança, histórico familiar médico, nível escolar, origem étnica, religião, profissão, hobbies, entre outras aptidões e habilidades.

Na sociedade contemporânea, o desejo de aperfeiçoamento do ser humano e do próprio filho para a continuidade de um legado é notório. Buscam-se indivíduos perfeitos, com atributos psíquicos e morais desejáveis culturalmente e físicos conforme um padrão de beleza ideal. Por isso, essa tecnologia de gerar bebês geneticamente programados tende a crescer mundialmente, sobretudo com a técnica de edição de DNA, o que, por ora, é proibida no Brasil.

Diante desse cenário tecnológico, este artigo tem por objetivo identificar qual o tipo de liberdade se adequa ao fato de um indivíduo poder gerar filhos geneticamente programados, selecionando aqueles sem determinada doença genética. Para tanto, inicialmente, deve-se analisar o conceito de liberdade, apresentando as distinções entre a liberdade dos antigos e dos modernos, assim como aquela defendida pelos liberais e pelos republicanos, trazendo enfoque na liberdade positiva e negativa, defendida por Isaiah Berlin.

Após, será apresentado, de forma breve, o conceito e evolução da autonomia privada frente aos referenciais bioéticos, de modo a justificar a viabilidade de concretização do diagnóstico genético pré-implantacional. Por fim, analisar a liberdade de selecionar o "melhor 
embrião" para poder gerar filhos sem doenças genéticas, verificando em qual modalidade de liberdade se adequa tal hipótese.

Neste estudo, utilizou-se como metodologia de pesquisa o método dedutivo de investigação e como técnica de pesquisa empregou-se a pesquisa bibliográfica específica acerca do tema, de modo a embasar as premissas que serão consignadas neste estudo.

\section{LIBERDADE}

A liberdade é objeto de estudo desde os tempos antigos, e, em razão de sua complexidade advinda dos diversos sentidos, conceitos e interpretações, continua, no século XXI, sendo alvo de fervorosos debates no campo social, político, ético, moral, filosófico.

Neste artigo, no entanto, restringe-se o estudo da liberdade quanto às distinções dos antigos e dos modernos, assim como aquela defendida pelos liberais e pelos republicanos, trazendo enfoque a liberdade positiva e negativa.

A discussão contemporânea acerca da liberdade conformou-se de forma sistemática através da distinção de Isaiah Berlin entre liberdade negativa e positiva, a qual generaliza a distinção de Benjamin Constant entre a liberdade dos modernos e a liberdade dos antigos (PETTIT, 2004, p. 117).

Benjamin Constant (1985, p. 3), ao comparar a liberdade dos antigos com a liberdade dos modernos, assevera que o objetivo daquelas "[...] era a partilha do poder social entre todos os cidadãos de uma mesma pátria", enquanto que dos modernos era a “[...] segurança dos privilégios privados; e eles chamam liberdade as garantias concedidas pelas instituições a esses privilégios."

Para Constant, a verdadeira liberdade moderna é a liberdade individual, sendo a liberdade política a sua garantia e é, desse modo, indispensável. Contudo, adverte que "[...] pedir aos povos de hoje para sacrificar, como os de antigamente, a totalidade de sua liberdade individual à liberdade política é o meio mais seguro de afastá-los da primeira, com a consequência de que, feito isso, a segunda não tardará a lhe ser arrebatada." (CONSTANT, 1985, p. 5).

Tanto a liberdade antiga quanto a moderna estão ameaçadas por perigos de espécies diferentes, Benjamin explica: 
O perigo da liberdade antiga estava em que, atentos unicamente à necessidade de garantir a participação no poder social, os homens não se preocupassem com os direitos e garantias individuais.

O perigo da liberdade moderna está em que, absorvidos pelo gozo da independência privada e na busca de interesses particulares, renunciemos demasiado facilmente a nosso direito de participar do poder político. (CONSTANT, 1985, p. 6/7).

Verifica-se que a liberdade antiga se aproximava ao que se entende por "liberdade política” e, para que isso fosse possível, as garantias individuais eram deixadas de lado, enquanto que a liberdade moderna fazia com que distanciássemos do poder político, restringindo nosso olhar aos interesses particulares.

Constant assevera que a felicidade não deve ser o único objetivo do gênero humano, porquanto seria uma meta estreita e o destino muito pouco nobre, e que a parte melhor da natureza humana, a inquietude perseguida pelos homens é justamente a liberdade política, afirmando que ela é "[...] o mais poderoso, o mais enérgico modo de aperfeiçoamento que o céu nos concedeu." (CONSTANT, 1985, p. 7).

Desse modo, é preciso combinar as duas espécies de liberdade, de modo que as instituições eduquem moralmente os cidadãos e que haja respeito a seus direitos individuais, protegendo sua independência (CONSTANT, p. 7).

Jhon Rawls discorda da importância dada por Constant à liberdade dos modernos em detrimento da liberdade dos antigos, sustentando, no entanto, que "[...] qualquer liberdade pode ser explicada mediante uma referência a três itens: os agentes que são livres, as restrições ou limitações de que eles estão livres, e aquilo que eles estão livres para fazer ou não fazer." (RAWLS, 2002, p. 218/219).

Ao discorrer sobre liberalismo e republicanismo, Pettit (2004, p. 117) apresenta alguns pontos em que tais correntes entram em conflito, um deles é como concebem a liberdade. Afirma o doutrinador que é consenso de que os liberais se preocupam particularmente com a liberdade negativa, asseverando que "El liberalismo es, primero y principalmente, la doctrina según la cual el Estado debería adoptar la forma que permita que la libertad negativa sea respetada o realizada al máximo dentro de una sociedade.” (PETIT, 2004, p. 118).

Os liberais afirmam que os republicanos favorecem uma concepção positiva da liberdade, no entanto, não há evidências que confirmem essa opinião, pelo contrário, a história tem mostrado a preocupação com a liberdade entendida como estar livre das interferências dos outros (PETTIT, 2004, p. 118). 
Assim, tanto o ideal republicano quanto o liberal coloca no centro da liberdade a questão da não interferência. Contudo, Pettit (2004, p. 119) explica a diferença, ressaltando que os liberais equipararam a liberdade com a ausência de interferência, já os republicanos equipararam a liberdade com estar protegido contra a exposição a interferência voluntária de outros, nada mais é do que estar seguro contra a tal interferência, é não estar dominado por outro.

Liberdade como não dominação é um ideal completamente diferente da liberdade como restrita a não interferência. A diferença vem do fato de que é possível ter dominação sem interferência e interferência sem dominação. Pettit exemplifica:

Yo puedo estar dominado por otro - por ejemplo, para ir al caso extremo, puedo ser el esclavo de otro- sin que ese otro realmente interfiera em ninguna de mis decisiones. Puede suceder que mi amo tenga un carácter amable y no intervencionista o puede simplemente suceder que yo sea lo suficientemente astuto como para ser capaz de salirme con la mía haciendo lo que yo quiera. Y, por otro lado, puedo realmente sufrir interferencia sin estar dominado por alguien: esto es, sin estar relacionado con alguien en términos de esclavo y amo. Consideremos la manera en que um gobierno de un Estado de derecho (PETTIT, 2004, p. 119/120)

Como bem frisa Isaiah Berlin (2002, p. 228/229) “[...] a liberdade é um termo cujo significado é tão poroso que não parece capaz de resistir a muitas das interpretações” e que seu estudo se restringe a duas acepções de liberdade: a negativa, que se resume a essa pergunta "Qual é a área em que o sujeito — uma pessoa ou grupo de pessoas — é ou deve ter permissão de fazer ou ser o que é capaz de fazer ou ser, sem a interferência de outras pessoas?”, e a positiva implica na resposta a essa outra questão: "O que ou quem é a fonte de controle ou interferência capaz de determinar que alguém faça ou seja uma coisa em vez de outra?" (BERLIN, 2002, p. 229).

Para Isaiah Berlin (2002, p. 229), a liberdade negativa consiste em poder agir sem ser obstruído por outros, a pessoa pode ser descrita como coagida quando outras pessoas restringem a sua atividade além de certo valor mínimo. "A coerção implica a interferência deliberada de outros seres humanos na minha área de atuação. Só não temos liberdade política quando outros indivíduos nos impedem de alcançar uma meta. A mera incapacidade de alcançar uma meta não é falta de liberdade política.” (BERLIN, 2002, p. 229).

No mesmo sentido, Philip Pettit (2004, p. 117/118) afirma que ser negativamente livre consiste em estar livre da interferência dos outros para perseguir as atividades que, dentro de 
uma cultura apropriada, um é capaz de alcançar sem a ajuda dos outros, nada mais é do que "[...] pensar lo que uno quiere, decir lo que uno piensa, circular como uno quiera, asociarse con cualquiera que lo acepte, y del mismo modo con el resto de libertades tradicionales."

A noção de liberdade positiva é trazida por Berlin nos seguintes termos:

O sentido "positivo" da palavra "liberdade" provém do desejo que o indivíduo nutre de ser seu próprio senhor. Desejo que minha vida e minhas decisões dependam de mim mesmo, e não de forças externas de qualquer tipo. Desejo ser o instrumento de meus próprios atos de vontade, e não dos de outros homens. Desejo ser um sujeito, e não um objeto; ser movido pela razão, por objetivos conscientes, que são meus, e não por causas que me afetam como que de fora. (BERLIN, 2002, p. 236/237).

A ideia trazida por Berlin sobre as formas negativa e positiva de liberdade pode aparentar não tão distante entre si do ponto de vista lógico, porquanto a primeira se refere à liberdade de não ser impedido por outros homens de escolher como agir, enquanto a segunda consiste na liberdade em ser o seu próprio senhor. Contudo, essas noções de liberdade foram se desenvolvendo historicamente em direções divergentes, tomando passos nem sempre logicamente respeitáveis, até entrarem em conflito direto uma com a outra (BERLIN, 2002, p. 236/237).

Para Phipi Petit ser positivamente livre requer a liberdade de participar na autodeterminação coletiva da comunidade, como na imagem de Constant da liberdade dos antigos, a liberdade tanto frente aos obstáculos internos da debilidade, compulsão e ignorância como frente aos obstáculos externos que provem da interferência dos outros, e inclusive a conquista de uma certa perfeição moral (PETTIT, 2004, p. 117/118).

As diferentes classificações de liberdades individuais compiladas por Jefferson, Burke, Paine, Mill possuem como argumento para manter a autoridade em xeque que "[...] devemos preservar um mínimo de liberdade pessoal, se não quisermos 'degradar ou negar nossa natureza",, não podendo permanecer totalmente livres e devendo abrir mão de alguma liberdade própria para preservar o resto (BERLIN, 2002, p. 233).

Isaiah Berlin (2002, p. 270/271) ainda ressalta que “[...] a extensão da liberdade de um homem ou de um povo para escolher a vida desejada por ele ou pelo grupo deve ser pesada contra as reivindicações de muitos outros valores, dos quais a igualdade, a justiça, a felicidade, a segurança ou a ordem pública são talvez os exemplos mais óbvios" e, por esse motivo, a liberdade não pode ser ilimitada. 
César Augusto Ramos apresenta um conceito mais moderno para a liberdade na sua versão positiva:

No sentido positivo, a liberdade é compreendida como a capacidade de autodeterminação do indivíduo, por meio da autonomia da vontade. De inspiração rousseauista, esse conceito de liberdade opera com a ideia de autonomia da vontade. Ela é positiva, porque indica a presença de uma faculdade de volição que decide (a vontade autônoma), mediante a qual o indivíduo age e escolhe sempre de acordo com as preferências racionais sobre como ele deve, livremente, viver. (RAMOS, 2011, p. 47).

Para Ramos ser livre significa controlar sua vida, sua própria vontade, ser o sujeito de suas escolhas e do modo de vida que pretende levar, não sendo instrumento e nem se submetendo a vontade de outro, permitindo, desse modo, o autogoverno pessoal na esfera privada e o autogoverno coletivo na esfera pública (RAMOS, 2011, p. 48).

Dentro desse cenário, verifica-se que a noção de liberdade trazida por esses inúmeros autores, sobretudo aquela mais contemporânea, traz a ideia de vontade livre de interferência de circunstâncias externas, a qual se traduz na autonomia da vontade, a qual será devidamente analisada no próximo capítulo.

\section{AUTONOMIA PRIVADA E PRINCÍPIOS BIOÉTICOS}

O princípio da autonomia da vontade ganhou grande importância durante o Estado Liberal, em que o indivíduo passou a ser valorizado e, como consequência, sua vontade. Essa autonomia permitiu que as partes estipulassem o que melhor lhes interessassem, escolhendo as cláusulas e condições do contrato, sem qualquer intervenção (AMARAL; HATOUM; HORITA, p. 267).

Com o Estado Social, “[...] o princípio da autonomia da vontade passa por um processo de reavaliação crítica devido a intervenção crescente do Estado, razão pela qual advém a ideia de autonomia privada" (AMARAL; HATOUM; HORITA, p. 270), que era entendida como o poder conferido aos particulares para autorregularem-se por meio de contratos, com limites impostos pelo Estado.

Nessa época, "a autonomia vem a ser gradativamente limitada por princípio e normas que, regulando os interesses fundamentais do Estado ou estabelecendo, no direito privado, as 
bases jurídicas da ordem econômica e moral da sociedade, passam a constituir a chamada ordem pública”. Não obstante a autonomia privada seja limitada pela ordem pública e pelos princípios da justiça contratual e da boa-fé, ela ainda permanece como princípio fundamental (AMARAL, 2006, p. 101).

Como bem ressaltado por Baez e Lima, “[...] a autonomia da vontade sem limites tornou-se insustentável, persistindo a autonomia privada" (BAEZ; LIMA, p. 2016, p. 120/121) e com o processo de "constitucionalização do Direito Privado", passou-se a valorizar de fato a pessoa humana, com vistas a tutelar sua dignidade, e abandonou-se uma ideia de patrimonialismo, de conteúdo meramente econômico.

Nesse cenário, surge o que se denomina de autonomia privada existencial ou autodeterminação, podendo “[...] ser compreendida no poder que o indivíduo tem de se autorregulamentar, sem que haja interferências externas, inclusive estatal e sua importância no Biodireito se deve justamente pelo objeto negocial, ou seja, interesses personalíssimos." (ESPOLADOR; BERMEJO, 2017, p. 64).

Conforme leciona Rose Melo Vencelau Meireles (2016, p. 110), a autonomia privada possui relação direta com o reconhecimento da pessoa humana como fim em si mesmo, visto que "é uma forma de expressão de sua dignidade e individualidade próprias" (apud RIBEIRO, 1999, p.22-23), e, de corolário, “a autonomia privada deixa de ser um conceito técnico para se transformar num conceito de valor" (apud RIBEIRO, 1999, p. 32).

Meireles explica ainda que a noção de autonomia privada se funde em uma base valorativo e, por isso, “a autonomia privada não é concebida como valor em si mesmo e postula um positivo juízo de merecimento por meio da observância de outros princípios também fundamentais, especialmente, o de tutela da dignidade da pessoa humana." (MEIRELES, 2016, p. 110).

Nesse contexto, a autodeterminação, seja na concepção jurídica - enquanto corolário do direito negocial - seja na concepção bioeticista, revela-se relevante. Corroborando o exposto tem-se o posicionamento de Espolador e Pavão:

Dessa forma, negócios biojurídicos celebrados tem como fundamento esse principio bioético, por isso é oportuno citá-lo. Todavia, é nítida a sua relação com a autonomia privada, enquanto esta trata de forma ampla de todas as questões privadas envolvendo a pessoa, no âmbito jurídico, a bioética 
apresenta um principio que não tem efeito jurídico, contudo, apresenta os mesmos conceitos existentes, mas voltados para o âmbito médico. (ESPOLADOR, PAVAO, 2019, p.97)

No entanto, há necessidade de se impor limites a essa autodeterminação, mormente quando se referem a questões existenciais ligadas ao Biodireito. Como assevera Regina Sauwen e Severo Hryniewicz (2000, p. 74), o Biodireito, inserido nos chamados direitos de quarta geração, possui por finalidade "normatizar os efeitos da revolução biotecnológica sobre a sociedade em geral." Ressalta ainda:

Amparando-se nas reflexões da bioética, cabe ao biodireito pensar tanto as normas quanto os critérios de decisão sobre as inovações da biotecnologia. A inspiração que lhe advém da bioética reside, sobretudo, nos princípios que esta sugere no tocante à finalidade e ao sentido da vida humana e no que tange aos fundamentos das obrigações e dos deveres sociais. (HRYNIEWICZ; SAUWEN, 2000, p. 47).

Portanto, o Biodireito possui como fonte imediata a bioética, considerada como a ética das ciências da vida, a qual surgiu na década de 70 e pautou-se em três princípios básicos, que foram consagrados no Belmont Report (Relatório Belmont), documento que foi criado pela Comissão Nacional para a Proteção dos Seres Humanos em Pesquisa Biomédica e Comportamental, constituída pelo Congresso norte-americano.

Um dos princípios é o da autonomia, em que considera o paciente capaz de autogovernar-se, fazendo suas opções e agindo conforme orientação dessas deliberações tomadas, sem qualquer coação ou influência externa (DINIZ, 2011, p. 38). Já o princípio da beneficência nada mais é do que “[...] não provocar danos, maximizar os benefícios e minimizar os riscos possíveis, buscando o bem estar do enfermo.” (SÉGUIN, 2001, p. 41).

Para Maria Helena Diniz (2011, p. 39), o princípio da beneficência se desdobra no da não maleficência, que consiste na obrigação de não acarretar dano intencional. $O$ terceiro e último princípio é o da justiça, o qual “[...] exige uma relação equânime nos benefícios, riscos e encargos, proporcionados pelos serviços de saúde ao paciente” (DINIZ, 2011, p. 40).

Estes princípios ou referenciais bioéticos, com caráter deontológico, não podem ser minimizados, porquanto, ainda que sem responsabilização jurídica, devem nortear as condutas 
voltadas às novas biotecnologias, como o diagnóstico pré-implantacional, objeto deste breve ensaio.

Portanto, esses são os principais paradigmas que devem nortear as soluções a serem encontradas para as difíceis questões ético-jurídicas que estão surgindo com os avanços biotecnológicos do mundo contemporâneo. Um exemplo disso é a prática biotecnológica que permite selecionar artificialmente um embrião com a finalidade de gerar um filho sem as alterações genéticas causadoras de doenças, o que será explorado a seguir.

\section{SELEÇÃO DO "MELHOR" EMBRIÃO MEDIANTE O DIAGNÓSTICO GENÉTICO PRÉ-IMPLANTACIONAL}

A revolução biotecnológica de edição de DNA humano, que vem sendo desenvolvida desde a década de 1990, vem ganhando força, sobretudo com o surgimento de técnicas avançadas, que permitem eliminar trechos específicos do DNA, introduzindo novos genes no local, editando-se, assim, tanto células geminativas (como óvulos, espermatozoides, embriões no estágio inicial de formal) quanto somáticas (FURTADO, 2019, p. 224).

Essa modificação genética em embriões é desaprovada em grande parte do mundo, e, no Brasil, há disposição expressa no art. 6º, III, da Lei de Biossegurança (Lei 11.105/2005), proibindo a prática de engenharia genética em célula germinal humana, zigoto humano e embrião humano.

Com efeito, permite-se tão somente a seleção de embriões submetidos a técnica de diagnóstico de alterações genéticas causadoras de doenças. Confira-se o que dispõe a Resolução do Conselho Federal de Medicina n. ${ }^{\circ}$ 2168/2017:

VI - DIAGNÓSTICO GENÉTICO PRÉ-IMPLANTACIONAL DE EMBRIÕES

1. As técnicas de RA podem ser aplicadas à seleção de embriões submetidos a diagnóstico de alterações genéticas causadoras de doenças - podendo nesses casos ser doados para pesquisa ou descartados, conforme a decisão do(s) paciente(s) devidamente documentada em consentimento informado livre e esclarecido específico.

2. As técnicas de RA também podem ser utilizadas para tipagem do sistema HLA do embrião, no intuito de selecionar embriões HLA- compatíveis com algum irmão já afetado pela doença e cujo tratamento efetivo seja o transplante de células-tronco, de acordo com a legislação vigente. 
3. O tempo máximo de desenvolvimento de embriões in vitro será de até 14 dias.

Portanto, o presente estudo se restringe a discutir a seleção embrionária decorrente do diagnóstico genético pré-implantacional (DGPI), que nada mais é do que uma biópsia realizada no embrião para buscar alterações cromossômicas e detectar mutações genéticas que podem dar origem a doenças genéticas, realizando um verdadeiro mapeamento da via embrionária. Assim, conhecendo o genoma do embrião, os pais podem decidir implantá-lo ou não. Nesse momento, portanto, surge a discussão que tipo de liberdade detém esses genitores.

Especificamente quanto a esse procedimento, Jurgen Habermas (2004, p. 26) critica a ideia de que o recurso ao aludido diagnóstico genético “deve ser considerado por si só como moralmente admissível ou juridicamente aceitável, se sua aplicação for limitada a poucos e bem definidos casos de doenças hereditárias graves que não poderiam ser suportadas pela própria pessoa potencialmente em questão.” Habermas (2004, p. 28/29) levanta um debate, ao indagar: "É compatível com a dignidade humana ser gerado mediante ressalva e, somente após um exame genético, ser considerado digno de uma existência e de um desenvolvimento?"

Sobre esse tema, Maria Helena Diniz (2011, p. 519) discorre que esse diagnóstico préimplantatório "seria uma porta aberta para o eugenismo, destruindo-se aquele que apresentar anomalia e beneficiando-se o dotado de melhor qualificação genética”, envolvendo, assim, o risco de modificação da espécie humana.

Pietro Perlingiei (p. 2002, p. 178), citando as normas constitucionais italianas, defende a manipulação genética em casos de graves impedimentos físicos ou psíquicos, causando perplexidade a legitimação de uma intervenção desta estirpe no embrião toda vez que for possível intervir no homem, ressaltando o risco de novas concepções da raça, o que representaria um retrocesso na história.

Regina Sauwen e Severo Hryniewicz (2000, p. 86) elogia a intenção de pesquisadores em libertar a humanidade das cerca de 3000 doenças hereditárias hoje conhecidas. Contudo, ressalta que é preciso dar atenção ao fato de que "[...] o conjunto de conhecimentos e técnicas para fins terapêuticos e louváveis, pode-se usá-los para fins duvidosos" e que tais manipulações podem afetar a constituição biológica de toda humanidade (HRYNIEWICZ; SAUWEN, 2000, p. 86).

Na ADI 3510 (STF, 2011, p. 263), o Ministro Menezes Direito menciona em seu voto a preocupação na utilização do diagnóstico genético de embriões: 
Será possível deixar de enxergar a gravidade do cenário montado, por exemplo, pelas técnicas de diagnóstico genético de embriões, em que se torna possível selecionar geneticamente aqueles que mereçam seguir adiante, descartando os demais, porque portadores de defeito genético? Isso quer dizer que é possível descartar aqueles embriões em que se diagnostica a trissomia do cromossomo 21, como se os portadores de Síndrome de Down não tivessem o direito de viver.

A busca da eugenia, da raça pura, do ser humano programado em laboratórios, não é, certamente, um ideal para a humanidade. Ao contrário, a diversidade que torna iguais os desiguais e transplanta a noção de igualdade para o tratamento jurídico dos desiguais como iguais na sua diversidade é um valor ético que não pode ser menosprezado.

Analisando-se a legislação brasileira e, sobretudo as normas deontológicas do Conselho Federal de Medicina por serem mais específicas ao caso, verifica-se que é possível a escolha de embriões, por meio do diagnóstico pré-implantacional, sem as alterações genéticas causadoras de doenças. Veja-se que o texto fala apenas em doenças, não especificando qual tipo de doença hereditária e qual a gravidade, deixando a cargo dos pais a escolha da implantação ou não do embrião in vitro.

Com efeito, essa aparente liberdade conferida aos indivíduos de escolherem quais embriões implantarem não deve ser absoluta, de modo que essas técnicas sejam utilizadas a bel prazer de seus pais. Essa liberdade deve possuir contornos razoáveis e proporcionais, de modo que as escolhas sejam prudentes, de modo a evitar o eugenismo, que se traduz na convicção de que é possível substituir os maus genes pelos bons, gerando, desse modo, uma nova espécie de humanidade livre de sofrimento e doenças hereditárias (DINIZ, 2011, p. 532).

Maria Helena Diniz (2011, p. 530/531), ao distinguir a eugenia positiva da negativa, assevera que a primeira "[...] consiste no conjunto de conhecimentos científicos e medidas higiênico-sanitárias que auxiliam a gerar filhos sadios", enquanto que a negativa tem por objetivo não só prevenir o nascimento de pessoa com patologia congênita, mas também evitar a transmissão do gene defeituoso. Portanto, ela defende que se pode acatar a eugenia positiva desde que as medidas sejam prudentes e possuam finalidade terapêutica, diminuindo o sofrimento do portador do mal genético ou prevenindo, sob a condição de que não induza à esterilização daqueles com deficiência física ou mental (DINIZ, 2011, p. 531).

Diante do explanado, verifica-se que a liberdade de gerar filhos que não contenha o gene de doença hereditária é uma liberdade sem dominação, porquanto os indivíduos possuem 
autonomia de realizar o diagnóstico pré-implantacional para selecionar o melhor embrião a ser implantado por meio da fertilização in vitro, sem que o Estado ou outra instituição a impeçam, tendo em vista a permissão pela Resolução do Conselho Federal de Medicina n. ${ }^{\text {o } 2168 / 2017 .}$

Contudo, há evidentes interferências no sentido filosófico, moral e ético, que foram levantados pelos autores citados, inclusive o Ministro do STF à época, Menezes de Cordeiro. ao proferir em seu voto na ADI 3510, ao apontar a gravidade do atual cenário biotecnológico, indaga se é possível, pela técnica de diagnóstico genético de embriões, selecionar aqueles que merecem viver, descartando embriões em que se diagnostica a trissomia do cromossomo 21 , como se os portadores de Síndrome de Down não tivessem o direito de viver (STF, 2011, p. 263).

Assim, pode-se dizer que a seleção embrionária mediante a técnica de diagnóstico préimplantacional decorre da liberdade negativa, e não da positiva. Conforme as ideias trazidas por Isaiah Berlin, a liberdade negativa consiste em poder agir sem ser obstruído por outros, enquanto que a positiva se traduz no desejo de decidir-se, sem forças externas de qualquer tipo.

No presente estudo, verifica-se que há liberdade negativa, porque, ao agir e selecionar o "melhor" embrião a ser implantado, por meio do diagnóstico pré-implantacional, gerando possível vida, não será impedida por outras pessoas ou até mesmo pelo Estado, vez que a Resolução do Conselho Federal de Medicina n. . 2168/2017 assim permite.

Contudo, não se pode falar em liberdade positiva, defendida por Berlin, porque a liberdade, consubstanciada na autonomia de selecionar o embrião que não possua anomalias ou patologias gênicas, é limitada, muitas vezes, por fatores externos de ordem moral, ética e filosófica que norteiam o poder de decisão de determinado indivíduo.

Com efeito, essas limitações advêm justamente de reflexões filosóficas, morais e éticas sobre início da vida, escolha dos embriões que merecem a tutela da vida, tal como a questão levantada acima sobre o eugenismo, o qual pode ensejar futura modificação da espécie humana, entre outras questões polêmicas.

Outra ponderação que poderia ser aventada também para impedir a liberdade de seleção do "melhor" embrião seria a discussão travada sobre as concepções acerca do embrião in vitro e sobre a indisponibilidade da vida humana pré-pessoal (HABERMAS, 2004, p. 106). Inclusive, há quem diga que "cada embrião já é a síntese incipiente da individualidade genética de um ser humano, logo, sua destruição seria um aborto eugênico” (DINIZ, 2011, p. 565). 
Além disso, como bem ressaltado por Isaiah Berlin (2002, p. 270/271), a extensão da liberdade de um homem deve ser pesada contras as reivindicações de muitos outros valores, sendo a igualdade, a justiça, a felicidade, a segurança ou a ordem pública exemplos mais óbvios, e conclui dizendo que a liberdade não deve ser ilimitada.

É nesse sentido, portanto, que a liberdade decorrente da seleção do "melhor" embrião mediante a técnica de diagnóstico pré-implantacional é aquela conceituada por Berlin como negativa, devendo ser afastada a noção positiva, porquanto há limites e valores a serem observados, ainda que indiretamente e superficialmente, no momento da tomada de decisão de selecionar o embrião que não tem anomalias ou doenças genéticas.

\section{CONSIDERAÇÕES FINAIS}

Diante do exposto e analisados os conceitos e classificações de liberdade, sobretudo as distinções entre liberdade positiva e negativa, defendida por Isaiah Berlin, verifica-se que a noção positiva se resume na liberdade em ser o seu próprio senhor sem qualquer interferência externa, ao passo que a noção negativa se refere à liberdade de não ser impedido por outros homens de escolher como agir.

Essa percepção negativista e positivista da liberdade carrega a ideia de vontade livre de interferências humanas e de circunstâncias externas, a qual se traduz na plena autonomia da vontade. Contudo, essa autonomia evoluiu, deixando de ser ilimitada e passando a se conceber uma autonomia privada pautada no valor da dignidade da pessoa humana, sobretudo frente às novas biotecnologias, passando a denominarem de autodeterminação.

Dentro desse contexto de autodeterminação e pautando-se nos referenciais bioéticos da autonomia, da beneficência e da justiça, é possível compreender e até mesmo solucionar questões ético-jurídicas que vem surgindo com os avanços biotecnológicos do mundo contemporâneo. Contudo, neste estudo, o foco biojurídico é na técnica de diagnóstico genético pré-implantacional, que permite selecionar artificialmente um embrião com a finalidade de gerar um filho sem as alterações genéticas causadoras de doenças.

Assim, verificada a viabilidade de concretização do diagnóstico pré-implantacional, constata-se a importância de analisar que tipo de liberdade está presente neste ato humano de escolher o "melhor" embrião a ser implantado mediante a prática biotecnológica referida 
acima, perquirido se há interferências humanas e/ou outros fatores externos que limitam essa liberdade.

Nesse sentido, de um lado, conclui-se que a seleção embrionária mediante a técnica de diagnóstico genético pré-implantacional decorre da liberdade negativa pregada por Berlin, porquanto não há interferência de outras pessoas ou até mesmo do Estado, sendo o procedimento devidamente autorizado pelo Conselho Federal de Medicina, na Resolução n. ${ }^{\circ}$ $2168 / 2017$

Por outro lado, a ideia de liberdade positiva resta afastada, no momento em que se verifica que há fatores externos de ordem moral, ética e filosófica, assim como valores que norteiam a tomada de decisão do indivíduo, ao selecionar o "melhor" embrião a ser implantado, sendo perceptível a conclusão de que a liberdade é limitada.

Em face disso, observa-se que o conceito de liberdade, mormente no que se refere às técnicas biotecnológicas voltadas à manipulação genética humana - neste caso, a seleção do embrião mais adequado a ser implantado no útero materno - revela-se pertinente para o direcionamento de tais condutas.

Assim, a liberdade negativa demonstra-se compatível com o procedimento mencionado, porquanto se reconhece a imprescindibilidade de limitações, com vistas ao respeito e observância dos valores e princípios jurídicos fundamentais no sistema jurídico brasileiro.

\section{REFERÊNCIAS}

AMARAL, Ana Claudia Corrêa Zuin Mattos do; HATOUM, Nida Saleh; HORITA, Marcos Massashi. O Paradigma Pós-Moderno Do Negócio Jurídico e a A Necessidade De Uma Nova Concepção Na Contemporaneidade. Scientia Iuris, Londrina, v. 21, n. 2, p. 261-297, jul. 2017. DOI: 10.5433/2178-8189.2017v21n1p262. ISSN: 2178-8189.

BAEZ, Narciso Leandro Xavier; LIMA, Germano Alves de. Os limites da autonomia privada em face da perspectiva civil-constitucional. Direitos Fundamentais \& Justiça, Belo Horizonte, ano 10, n. 34, jan./jun. 2016.

BERLIN, Isaiah. Dois conceitos de liberdade. Estudos sobre a humanidade: uma antologia de ensaios. Tradução Rosaura Eichenberg. São Paulo: Companhia das Letras, 2002. 
BRASIL. Conselho Federal de Medicina. Resolução n. ${ }^{\circ}$ 2168/2017. Publicado em 10.11.2017. Disponível em: < https://sistemas.cfm.org.br/normas/visualizar/resolucoes/BR/2017/2168>. Acesso em: 05.mar.2020.

. Lei n. ${ }^{\circ} 11.105$, de 24 de março de 2005. Lei de Biossegurança. Disponível em: <http://www.planalto.gov.br/ccivil_03/_Ato2004-2006/2005/Lei/L11105.htm>. Acesso em: 13.abril.2020.

Supremo Tribunal Federal. Acórdão e votos da ADI 3510. Disponível em: < http://redir.stf.jus.br/paginadorpub/paginador.jsp?docTP=AC\&docID=611723 >. Acesso em: 13.abril.2020.

CONSTANT, Benjamin. Da liberdade dos antigos comparada à dos modernos. In.: MONTEIRO, João Paulo e ou. Filosofia Política 2. Porto Alegre: L\&PM Editores (UNICAMP;UFRGS - com apoio do CNPQ), 1985.

DINIZ, Maria Helena. O estado atual do biodireito. 8. ed. rev., aum. e atual. São Paulo: Saraiva, 2011.

ESPOLADOR, Rita de Cássia Resquetti Tarifa; BERMEJO, Aracelli Mesquita Bandolin. A autodeterminação nos negócios biojurídicos: uma necessária releitura da autonomia privada sob o aspecto liberal. Revista de Biodireito e Direitos dos Animais, e- ISSN: 25259695, Brasília, v. 3, n. 1, Jan/Jun. 2017.

ESPOLADOR, Rita de Cássia Resquetti Tarifa; PAVÃO, Juliana Carvalho. Evolução dos negócios jurídicos. Questões atuais dos negócios jurídicos à luz do Biodireito: discussões sobre negócios biojurídicos./ [organizadoras] Rita de Cássia R. Tarifa Espolador, Daniela Braga Paiano - Londrina, PR: Thoth, 2019.

FURTADO, Rafael Nogueira. Edição genética: riscos e benefícios da modificação do DNA humano. Revista Bioética. Vol. 27, n² - 2019. Brasília/DF, Brasil, Conselho Federal de Medicina, 2019.

HABERMAS, Jürgen. O futuro da natureza humana. São Paulo: Martins Fontes, 2004.

MEIRELES, Rose Melo Vencelau. Negócios Biojurídicos. Negócio jurídico e liberdades individuais: autonomia privada e situações jurídicas existenciais./ coordenação de Everton Willian Pona, Ana Cláudia Corrêa Zuin Mattos do Amaral, Priscila Machado Martins./ Curitiba: Juruá, 2016.

PERLINGIERI, Pietro. Perfis do direito civil: introdução ao direito civil constitucional. Trad. Maria Cristina de Cicco. Rio de Janeiro: Renovar, 2002.

PETTIT, Philip. Liberalismo y republicanismo. In.: OVEJERO, Félix; MARTÍ, José Luís; GARGARELLA, Roberto (compiladores). Nuevas ideas republicanas: autogobierno y libertad. Barcelona: Paidós, 2004.

RAMOS, César Augusto. O modelo liberal e republicano de liberdade: uma escolha disjuntiva. Transformação, v. 34, n 1, p 43-66, 2011. 
RAWLS, Jhon. Uma teoria da justiça. Tradução Almiro Pisetta e Lenita M. R. Esteves. São Paulo: Martins Fontes, 2002.

SAUWEN, Regina Fiúza e HRYNIEWICZ, Severo. O direito "in vitro" - Da bioética ao biodireito. $2^{\text {a }}$ ed. Rio de Janeiro: Lúmen Juris, 2000.

SÉGUIN, Elida. Biodireito. Rio de Janeiro: Editora Lumen Juris, 2001. 